\title{
Misunderstanding, Misperception and Mistakes: The Logic of the Grail in Old French Arthurian Romance and Thomas Malory's Tale of the Sankgreal
}

\section{Martha Claire Baldon ${ }^{1}$ (D)}

Accepted: 1 August 2021 / Published online: 13 September 2021

(c) The Author(s) 2021

\begin{abstract}
This article seeks to resituate critical discussions about logic in the Old French Grail romances and Thomas Malory's Tale of the Sankgreal. Where previous scholarship has emphasised the mystical elements of the Old French Grail narratives to suggest alternate meanings for the Grail itself, this article reads the Grail miracles as structuring devices that reflect classical theories of dialectic and demonstrative argumentation. Through examining one example from Chrétien de Troyes' Perceval, the Didot-Perceval, The Vulgate Cycle Queste del Saint Graal, and Thomas Malory's Tale of the Sankgreal, this article also highlights fundamental similarities between the logical systems underlying each Grail narrative that are not restricted by language or date of composition. Thus, the article depicts Malory not just as consciously drawing upon the Vulgate Queste del Saint Graal, but also as unconsciously inheriting elements from each of his Old French predecessors.
\end{abstract}

Keywords Logic · Holy grail · Thomas Malory · Queste del Saint Graal · Chrétien de Troyes $\cdot$ Perceval $\cdot$ Didot-Perceval

\section{Introduction}

Towards the end of Thomas Malory's Tale of the Sankgreal (1469), Lancelot arrives at midnight in a rudderless boat "before a castell which was rych and fayre, and on the backe syde there was a posterne opened towarde the see, and was opyn withoute ony kepynge, save too lyons kepte the entré" (p. 772). ${ }^{1}$ Lancelot then hears a voice which tells him to "go oute of this shyppe, and entir into the castel where thou shalte see a grete parte of thy desire" (p. 772). To Lancelot's eyes, the lions that guard the

\footnotetext{
1 All citations from the Tale of the Sankgreal are taken from Peter Field's 2017 edition.

Martha Claire Baldon

baldon@hhu.de

$1 \quad$ Heinrich-Heine Universität, Dusseldorf, Germany
} 
threshold to Corbenic represent the final barrier between himself and the Holy Grail, the elusive and much sought after object of his desire: beyond the lions there is "no gate nor doore but hit was opyn" (p. 773). Lancelot responds to the lions much as we might expect any knight in a medieval romance to do: he draws his sword and prepares to approach them without concern. However, this action is instantly physically checked by a dwarf, who "smote hym on the arme so sore that the swerde felle oute of his honde" (pp. 772-773) and verbally rebuked by a voice, which states "O man of evylle fayth and poore beleve! Wherefore trustiest thou more on thy harneyse than in thy Maker? For He myght more avayle the than thyne armour, in what servyse that thou arte sette in" (p. 773). Having come so far, Lancelot is found wanting as he stands on the threshold of success, not out of a lack of ability or even sincere faith, but due to a lack of understanding.

This is not the only moment in the Sankgreal in which the expectations and rules that inform the behaviour of the knights fail to produce the expected positive results. Throughout the Sankgreal, responding to the aventures of the Grail using the same behaviours and methods of interpretation required in more secular romance narratives yields negative results (and much confusion) for the hopeful knights. Indeed, the knights are consistently informed that the arrival of the Grail has changed the expectations of the Arthurian world, and that a new mode of interpretation and behaviour is required for success in this holy quest. When Lancelot witnesses a tournament between a group of knights dressed in black and a group of knights dressed in white, for example, he interprets the scene according to his understanding of secular chivalric conventions and decides to "helpe there the wayker party in increasyng of hys shevalry" (p. 719) (emphasis mine). Lancelot subsequently suffers an overwhelming defeat and mourns that "never or now was I never at turnemente nor at justes but I had the beste. And now I am shamed, and am sure that I am more synfuller than ever I was" (p. 720). A recluse who interprets the aventure for Lancelot confirms his mistake, and explains that "thou behlede the synners and the good men, and whan thou saw the synners overcom thou enclyned to that party for bobbaunce and pryde of the worlde, and all that muste be leffte in that queste" (p. 721). In the Grail quest a desire to increase one's chivalric reputation is represented as tantamount to pride. The problems that the knights face centre on their inability to interpret the aventures before them and perceive how they should react: they are problems of logic.

This article argues that in the Old French Grail narratives the aventures that the knights encounter function according to a distinctive type of logic, in which many of the familiar expectations and features of more secular Arthurian romance are reworked according to the heightened spiritual priorities of the Grail quest. Through drawing upon one example from Chrétien de Troyes' Perceval (1190), the DidotPerceval (c. 1200), and the Queste del Saint Graal (c.1225), I will analyse the process of logic deployed by each text to highlight the genetic similarities between the Grail narratives. ${ }^{2}$ In Publishing the Grail in Medieval and Renaissance France

\footnotetext{
${ }^{2}$ I have chosen a selection of Old French Grail narratives to discuss in this article alongside the Morte Darthur. However, this is not to say that the other narratives of the Grail do not conform to the ideas about logical argumentation that are discussed here. The Old French Perlesvaus (early thirteenth century), for example, also follows the logical patterns that I identify in this article. Indeed, in this text the
} 
(2017), Leah Tether explains that the way in which publishers treated the Grail narratives was different from the way in which they treated and collated more secular Arthurian romances:

identifiable trends in the way in which Grail texts were interpolated, compiled and bound into volumes over time strongly indicate a growing awareness of an inherent, and possibly even generic, link between French Grail texts (Tether, 2017).

I want to suggest that this generic relationship, identified by Tether as being a feature of the French Grail romances, extends to Malory's Sankgreal and is therefore not restricted by language or date of composition. Through considering an example from the Sankgreal alongside the examples from the earlier Old French Grail narratives I will suggest that Malory is interacting with the same models of logic as his sources. In analysing the narrative pattern of the Grail narratives, I draw upon medieval theories of logical argumentation, to suggest that the deployment of the Grail miracles in each text can be further understood in relation to advances in logical theory in the thirteenth century.

The relationship between logic and twelfth century literature has received some scholarly attention, largely to do with the fact that, as Virginie Greene notes, "the revival of logic in the Middle Ages coincides with the emergence of Old French literature, in the same geographical area and at about the same time (the late eleventh century)" (Greene, 2014). Romance narratives have also frequently been the focus of discussions regarding logic. ${ }^{3}$ However, critics have not yet specifically addressed the question of logic in the Grail romances. Greene writes that one of the reasons that considering questions of logic in Yvain is relevant is because the writer "insists upon the thought process of his hero" (Greene, 2014). ${ }^{4}$ In the Grail narratives the reader is invited to interact with the knights' struggle to interpret the higher significance of the aventures that they meet and thus choose a successful course of action. It is precisely the "thought process" of each knight that we follow and are ultimately asked to judge. As such, questions of logic and perception are particularly significant to this sub-genre of Arthurian romance.

Footnote 2 (continued)

importance of the relationship between demonstrative argumentation and dialectical reasoning is highlighted further by the fact that the dialogue between knights and hermits frequently takes the form of questioning. When Gawain arrives at the Castle of Enquiry after retrieving the bleeding sword, for example, he narrates each part of his former aventures to a priest, asking what they mean. The priest then recasts the Arthurian aventures that Gawain has encountered as Christian miracles, and explains the distinct significance of each. In 'Malory and the Post-Vulgate Cycle' Elizabeth Archibald also discusses the influence that the Post-Vulgate cycle has on the Morte Darthur (Archibald, 2018).

3 One of the romances featuring most frequently in discussions of logic in medieval literature is Chrétien de Troyes's Yvain. As Tony Hunt points out, "dialectical and syllogistic reasoning is incontrovertibly present in Laudine's imaginary argument with the slayer of her husband (1760ff.), in Yvain's ratiocination on how he may love his enemy (1444 ff.) and the narrator's presentation of the paradox of love and hate in the combat of Yvain and Gauvain (6002 ff.)" (Hunt, 1977).

${ }^{4}$ Greene uses this line of reasoning to suggest that this implies that Chrétien "knows something about syllogisms, which he should if he went through the trivium" (Greene, 2014). 
Critical readings of the way in which the narrative of the Vulgate Queste functions have generally focussed on the possible Cistercian influence on the text, using parallels between the Queste and various religious writings to suggest different ways of reading the Grail both as a symbol and object. Albert Pauphilet first highlights the importance of the Cistercian influence on the narrative of the Queste del Saint Graal in Études sur la Queste del Saint Graal (Pauphilet, 1921), ideas which were supported by Étienne Gilson's article "La mystique de la grâce dans La queste del Saint Graal" (Gilson, 1925). Where Pauphilet argues that the Grail is "la manifestation romanesque de Dieu" (Pauphilet, 1921), Gilson reads the Queste through a theological framework to conclude that "li Saint Graax, ce est la grace del Saint Esperit" (Gilson, 1925). Myrrah Lot-Borodine uses close textual analysis to emphasis the relationship between the Queste "and the most metaphysical of the Cistercian fathers" (Matarasso, 1979), to suggest that the Grail symbolises the Holy Spirit. Pauline Matarasso references Pauphilet's work on the Cistercian influence on the Queste in the introduction of her translation of the Quest of the Holy Grail (1969) and later study The Redemption of Chivalry (1979). Rather than using a theological framework of analysis to suggest an alternate meaning for the Grail (or to support an existing suggestion), this article will focus instead on the way in which the Grail miracles function as structuring principles of each narrative. This article argues that the structure of Grail quest narratives can be more clearly understood through a comparison with the classical theories of logic that were gaining popularity at the same time that many of the Old French Grail quest narratives were written. attention paid to questions of narrative logic in Malory's Grail quest has frequently focussed on the connection between the earlier story of Balin and the Sankgreal. ${ }^{5}$ Thomas C. Rumble, for example, focuses on Malory's inclusion of a reference to the story of Balin in the Sankgreal to suggest an original attempt on the part of Malory to unify the stories of the Morte Darthur. Thomas Crofts connects the inclusion of the references to Balin to the attempt of the post-Vulgate Cycle, and thus also Malory, "to 'make sense' of the main part of the story, and by means of various new stories to make the whole cohere" and "contain wayward material" (Crofts, 2006). Kevin Whetter further highlights the connection between the stories of Balyn, Arthur and Galahad: "the only knights in the whole of the Morte Darthur thus to draw swords from magic scabbards or stones are Balyn, Galahad, and Arthur himself' (Whetter, 2005). In this article, however, my focus is not on the way in which the logical system of the Sankgreal unifies or does not unify this text within the Morte Darthur as a whole, but rather on the way in which the Grail miracles themselves function as a logical system that the knights must interpret and we must understand to make sense of the quest. For this reason, this article will focus on moments at which the texts present the knights as needing to reason what course of action to take in order to bring an aventure to a successful close.

\footnotetext{
5 Malory's choice to include this episode, which comes from the Post-Vulgate Cycle, and is not found in Malory's principle source, the Queste del Saint Graal, has frequently been read by critics as part of Malory's attempt to tying the events of the Grail quest to the more secular Arthurian world.
} 
This article defines logic as the process of deductive reasoning that the knights are supposed to follow to interpret the aventures that they meet on the Grail quest. The opening of the Grail quest marks a clear shift in the type of deductive reasoning that the knights need to follow from that seen in more secular Arthurian romance. Indeed, according to the expectations of more secular romance texts some of the decisions that the knights must make appear to be distinctly illogical. Choosing to lower your sword when faced by two growling lions, as illustrated above, directly contravenes the focus on physical prowess that dominates descriptions of Lancelot's successes in earlier parts of both the Vulgate Cycle and the Morte Darthur. ${ }^{6}$ In each of these texts the logic that the knights need to follow is in some ways the antithesis of what we might ordinarily think of as "common sense". It is un-common sense that the knights need to recognise and apply in order to progress on the Grail quest.

The first part of this article will look at conceptualisations of logic in more secular parts of the Morte Darthur, to identify some of the ways in which the Sankgreal presents a distinct shift in expectations of behaviour and methods of learning from earlier parts of the text. From here, I will focus on the development of ideas surrounding demonstrative and dialectic logical theories throughout the thirteenth century, and highlight the ways in which the Old French Grail narratives respond to these ideas. Finally, I will analyse textual moments from Chrétien de Troyes' Perceval, the Didot-Perceval and the Vulgate Cycle Queste del Saint Graal to examine the way in which each text utilises contemporary logical theory, and thus provide the context for the logical patterns seen in the Sankgreal.

\section{Logic in Secular Parts of the Morte Darthur}

In the normative Arthurian world, the statement made by Chaucer's Wife of Bath that "Experience, though noon auctoritee/Were in this world, is right ynogh for me" might characterise the way in which a young and inexperienced knight proves his worth and improves his chivalric ability (Benson, 2008, 11. 1-2). In the story of La Cote Male Tayle in the Tristram section of the Morte Darthur, for example, Mordred explicitly highlights the importance of experience to developing chivalric prowess in a defence of La Cote Male Tayle after he is unhorsed during a joust:

I warne you playnly he is a good knyght, and I doute nat but he shall preve a noble man. But as yette he may nat sytte sure on horsebacke, for he that muste be a good horseman hit muste com of usage and excercise [...] For in lyke wyse Syr Launcelot du Lake, whan he was fyrste made knyght, he was

\footnotetext{
6 This sudden change in practice also leads the knights (and the reader) to reconsider earlier parts of the Morte Darthur in light of these new expectations. As Douglas Kelly summarises, "the literal account of Lancelot's achievements follows the natural order. But the reinterpretation of his life and the condemnation of his sinful love for Guinevere in the Queste, almost at the end of the cycle, forces the reader to make a complete re-examination and interpretation of his life in the earlier parts" (Kelly, 1992). Similarly, in the Manessier Perceval Continuation (c. 1230), for example, when a hermit explicitly informs Perceval that to kill another knight is a sin both the readers and Perceval himself is forced to reconsider all of his past chivalric triumphs in light of this new information.
} 
oftyn put to the worse on horsebacke, but ever uppon foote he recoverde his renowne. (p. 366)

Fighting on horseback, Mordred suggests, is a skill that must be learned, and a young knight's initial inability to do this does not reflect a lack of chivalric potential. $^{7}$

Experience, however, is not only the means by which a knight improves his physical prowess (as Malory's Mordred states) and thus sets his reputation as a knight; it is also how he learns to interpret aventures, and, therefore, how he develops the ability to choose a successful course of action. This process is important not just to the Knights of the Round Table, but to King Arthur as well. At the beginning of the Morte Darthur, Arthur himself has to be taught the right way to react to aventures by Merlin when he responds to a potential aventure with inactivity:

Nay seyde Merlyon, ye may nat leve hit so, thys adventure, so lyghtly, for thes adventures muste be brought to an ende, othir ellis hit woll be the disworshyp to you and to youre feste. (p. 82)

Arthur's initial reaction marks an inability to interpret the significance of the aventure, and thus take the action expected of a good king. Rather than proposing anyone pursue the aventure, Arthur is initially glad that an aventure which caused in "such a noyse" (p. 81) has left his hall. However, and as Merlin explains, failing to respond to an aventure correctly and with the appropriate level of action results in "disworshyp". The Grail narratives, which require the physical world to be interpreted in the light of Christian doctrine, both replicate and complicate this learning process; before the knights can start to learn the correct way to interpret the "merveilles del Graal" they must first "unlearn" their usual mode of response to more secular aventures. A failure to do this not only results in a failure to progress on the quest, but the offending knight will also face "disworshyp" of the kind frequently suffered by Lancelot throughout his experience on the Grail quest.

More secular romance narratives operate according to a form of logic that relies upon fate and chance. James Wade suggests that, in certain sections of the Morte Darthur, the order of interlaced episodes seems to "give way to unmotivated or at least under-motivated sequences in which the characters appear to be at the mercy of chance and the action of the narrative tends to become arbitrary" (Wade, 2013). To illustrate this point, Wade discusses Malory's treatment of his source in the "Gawain, Ywain and Marhalt" section of the Morte Darthur, in which the three knights meet "thre damesels" (p. 127) sitting by a stream. When the knights question why the women are sat by the fountain they receive the reply that "We be here [...] for this cause: if we may se ony of arraunte knyghtes to teche hem unto straunge aventures" (p. 127). The sequences that follow, Wade argues, illustrate a distinct type of logic that is based on "knowing through analogy", rather than a causal relationship between episodes (Wade, 2013).

\footnotetext{
7 This incident is unusual, since youthful chivalric ineptitude is not often shown elsewhere in Malory's Morte Darthur.
} 
The Grail romances complicate this understanding of aventure by relating it directly to knights' spiritual state. As Wade summarises, "in the Grail Quest the rules of the game are different, and the knights on that quest are faced with a logic slightly at an angle to that of the ordinary Malorian world" (Wade, 2013). Rather than following the logical pattern of earlier parts of the Morte Darthur, I want to suggest that the Sankgreal follows the logical system illustrated by the Thirteenth Century Old French Grail narratives. The sudden shift in logical parameters at the start of the Sankgreal is, however, something that the knights themselves find difficult to comprehend, as can be seen in Gawain and Ector's reaction to the lack of aventures that each has met since beginning the quest: "And so they tolde everyche othir, and complayned them gretely, that they coude fynde none adventure" (p. 723). Gawain, indeed, goes one step further and articulates a desire to give up on the Grail quest altogether due to this lack of aventure: "truly [...] I am ny wery of thys queste, and lothe I am to folow further in straunge contreyes" (p. 723). Gawain, deep in the throes of what Corey Olsen has termed his "spiritual aridity", does not understand that in this holy quest aventures materialise (or not) in response to the decisions and choices made by the knights themselves (Olsen, 2007). While Gawain refuses to engage with the spiritual lessons of the quest his landscape will remain blank.

The heightened priority of religious values throughout the Grail quest means that a knight must interpret each aventure he faces in light of the Christian doctrine to successfully overcome it. To illustrate the importance of interpretation, the Grail narratives describe the journeys undertaken by each knight as uniquely personal experiences. Gone are the days where knights can expect to find a missing companion by following the aventures that this companion has already completed. Instead, the Sankgreal emphasises the physical separation between the successful and unsuccessful Grail knights. ${ }^{8}$ When Gawain attempts to follow Galahad at the beginning of the Sankgreal, for example, he is told that "he woll nat of youre felyship [...] for ye be wycked and synfull, and he ys full blyssed" (p. 690). This initial separation of knights according to their spiritual state is further emphasised later in the text when Gawain asks Hector which of the Knights of the Round Table he has met while on his quest. Hector states that although "I have mette with twenty knyghtes that be felowys of myne, and all they complayne as I do" (p. 723) he "can nat hyre of [Launcelot], nother of Sir Galahad, Sir Percivale, and Sir Bors” (p. 723). Gawain's response to this, "lette hem be [...] for they foure have no peerys" (p. 723) further highlights the relationship between spiritual understanding and physical separation.

\footnotetext{
8 A distinction can be drawn here between the Grail romances that feature Perceval as the most successful Grail knight, and those which feature Galahad. In the Perceval Grail romances the quest for the Grail is a quest that Perceval embarks upon alone. The quest for the bleeding lance that Gawain undertakes is a similarly individual experience that Gawain alone engages with. In contrast to this, in the Vulgate Cycle Queste onwards the quest for the Grail becomes a communal experience. Although the knights know that it is Galahad who will achieve the Grail it does not stop them from engaging with the quest itself, and the texts draw frequent parallels and comparisons between the fates of the various knights.
} 
As Elizabeth Archibald notes, in the Grail quest "sin becomes a new and ominous reason for losing or being denied fellowship" (Archibald, 1992). ${ }^{9}$

In the Sankgreal, however, the knights are not expected to make this sudden interpretative leap alone. Just as Arthur has Merlin to direct his reactions to marvellous events in the example from the Morte Darthur discussed above, on the quest of the Holy Grail the knights are instructed and directed by a number of religious figures, including priests, abbots, recluses and hermits, who counsel the knights to enable them to understand the miracles that they encounter. This dialogue between the knights and the religious figures becomes one of the structuring principles of the Sankgreal and its sources.

\section{Dialectic and Demonstrative Argumentation}

This article suggests that the way in which this interaction between the knights and the hermits should be read can be further understood in relation to medieval forms of argumentation. As the knights step into the Grail quest they enter into what can be conceptualised as a dialogue with God, in which the Grail miracles act as a form of argumentation, designed to compel both the knights and the readers to improve their spiritual understanding. At the beginning of the thirteenth century, when the Old French Grail quest narratives were being written, medieval philosophers drew a distinction between two primary modes of logical argumentation: dialectic arguments and demonstrative arguments. Dialectic arguments followed a similar pattern to the method of dialectic argumentation described by Socrates in the Platonic dialogues (Stump, 1986). According to Eleanor Stump, Socrates "discovers arguments [...] that he uses in oral disputation with some opponent to compel his opponent to agreement" (Stump, 1986). For this reason, dialectic arguments have to be persuasive, to compel a second party to change their view on a given topic. The conclusions reached by such arguments, however, are not necessarily true. In contrast,

a demonstrative argument such as a geometrical proof, begins (ultimately) with certain axioms, which are self-evidently true, and works by strict deductive steps from these self-evident truths to conclusions containing new information about the subject matter (Stump, 1986).

This view, that knowledge can only be produced by demonstrative arguments whose conclusions are unequivocally true, characterised thirteenth-century ideas about logic. ${ }^{10}$ However, medieval logicians also perceived that one potential problem with demonstrative arguments as a method of persuading an opponent to a certain point of view is that the first axioms (as described above) are often difficult for a non-specialist to understand. This makes the deductive steps that proceed from these first axioms impossible to follow. This difficulty in perceiving deductive steps

\footnotetext{
9 Archibald uses the same example to illustrate this point, and discusses Malory's substitution of "compaignie" with "felyship" (Archibald, 1992).

10 Stump outlines the changing use of the term 'dialectic' throughout the Scholastic period. For more information see Stump 1986.
} 
is mirrored in each of the Grail narratives. When the knights encounter a miracle, although they can tell that it has a symbolic significance, they are not often able to interpret the specific meaning of the aventure without assistance. ${ }^{11}$

Throughout the thirteen century, however, Scholastic perspectives questioned the nature of the distinction between the dialectic and the demonstrative, particularly in relation to the production of knowledge. Medieval scholars became increasingly interested in the Posterior Analytics in which Aristotle states that.

knowledge comes through "demonstration". By "demonstration" I mean a scientific syllogism and by "scientific" a syllogism the mere possession of which makes us know (Bouchier, 1901).

As John Marenbon elucidates, "for Aristotle, scientific knowledge is of facts which cannot be otherwise than they are; its objects are eternal and changeless" (Marenbon, 1987). The idea that a "true" knowledge and understanding of a given topic could only be gained through demonstrative arguments (those which Aristotle defines as 'true, primary, immediate, better than, anterior to and the cause of the conclusion' (Marenbon, 1901)) led medieval scholars to concentrate on two primary questions:

1) What are the ultimate criteria (rather than simple formal criteria) for the validity of inferences?; and 2) what sort of things in the world can be the subject of necessary and unchanging premises? (Stump, 1986)

The result of this questioning was a blurring of the boundary between dialectic and demonstrative methods of argumentation. The Grail narratives reflect the resulting connection between metaphysics and logic though their depiction of the Grail miracles. The hermits, priests, abbots and other religious figures who inhabit the Grail landscape and who provide explanations of the knights' experiences, fill in the deductive steps that the knights themselves are unable to perceive. As such, they provide the dialectic response to the demonstrative miracles. The marked increase in the length and complexity of exegetical explanation in each chronologically successive Grail narrative reflects the rise of Scholastic perspectives throughout the thirteenth century.

J. D. G. Evans suggests that the "dialectic proceeds by asking questions rather than making statements which distinguishes it from scientific demonstration" (Evans, 1977). Catherine Kavanagh further suggests that "rather than establishing absolute, incontrovertible, logical proofs, which is demonstration, dialectic aims to produce conviction" (Kavanagh, 2003). Kavanagh also states that.

\footnotetext{
11 A clear example of this can be seen in the Queste after Bohort witnesses a Pelican killing itself to revive its young. The Queste states that "Qvant Bohort vit ceste auenture. Si sesmerueille mout que ce puet ester. Car il ne set quell chose puist auenir de ceste semblance.' (p. 139) [“As Bors stood watching this phenomenon, he wondered, awe struck, what it signified, not knowing what reality might underlie the form" (p. 181)]. Similarly, the Sankgreal states that "What Bors saw thys he wyste well hit was a grete tokenynge" (p. 732), although again there is no suggestion that he understands what that meaning is.
} 
a notable use of the dialectical [...] occurs in those areas where demonstration would be impossible, for instance, in the question of the relation between the utterly transcendent God and his creation (Kavanagh, 2003).

It is, of course, exactly this relationship between God and his creation that the Grail narratives explore. When the knights request interpretations of a given aventure from a religious figure they engage in form of dialectic reasoning. The hermits and other religious figures do not only "fill in" and explain the spaces between each deductive step that connects the Grail miracle to the religious truth for which it stands, and so lead the knights to a practical action, they also often provide a compelling argument as to why the knight should follow this guidance. At the beginning of Lancelot's quest in the Sankgreal, for example, Lancelot is finally compelled to confess his love for Guinevere, previously concealed during his earlier confessions, after being told that "youre strengthe and your manhode woll litill avayle you and God be agaynste you" (p. 696). It is the advice given by similar religious figures, which draws upon Christian history and understanding, that each of the knights must accept and believe to progress towards the Grail. Reading the Grail miracles as examples of demonstrative arguments that reflect contemporary medieval ideas of logic therefore illuminates the progression from very little exegetical explanation in Chrétien's Perceval to the profusion of exegesis in the Vulgate Queste, as can be seen through the close analysis of a case study example from each of the texts.

\section{Logic in the Grail Narratives}

The narrative of Chrétien's Perceval is structured around a single moment of comprehension in which Perceval is supposed to witness the Grail procession, understand the story of resurrection and sacrifice for which it stands, and therefore ask whom the Grail serves in a series of instinctive logical steps. The ritualistic significance of the Grail procession would have been instantly recognisable to a medieval audience. Miri Rubin explains that,

Priests were seen as teachers, but above all as ritual performers of sacramental acts, those acts which tie the Christian world to God through repeated and reiterated procedures that only the priest could perform (Rubin, 1991). 
Although there is no priest present, the ritual bringing out of the candles, the bleeding lance and the Grail itself parallel medieval religious ceremonies. ${ }^{12}$ The Grail procession is thus described as a visual demonstration that ties the narrative Arthurian world to the Christian world, the Grail procession to a familiar religious ceremony and the divine truth for which it stands. However, in Chrétien's text Perceval misses the ritualistic significance of the procession, and rather than being moved to question its meaning he misapplies the advice earlier given to him by his chivalric advisor, Gornemant de Gohort, who informed Perceval that.

Nus ne puet ester trop parliers

Que sovant tel chose ne die

Que l'an li torne a vilenie,

Et li saiges dit et retrait:

Qui trop parole pechié fait (Mela, 1994, 11 1608-1612) ${ }^{13}$

[Anyone who is too talkative soon discovers he has said something that brings him reproach, and the wise man says and declares: "He who talks too much commits a sin". ( p. 402)]

Subsequently, as Perceval gazes at the procession he fails to ask 'Do grail cui l'anen servoit/Que toz jorz an son cuer avoit/La parole au prodome saige (1l. 31823185) [who was served from the Grail, for in his heart he always held the wise gentleman's advice (p. 421)]. The connection between Perceval choosing not to respond and the earlier advice he was given is repeated when the Grail passes Perceval for a second time, and we are told that.

Por lo prodome se tenoit

Qui docemant lo chastia

De trop parler, et il i a

Toz jorz son cuer, si l'en sovient (11. 3232-3235)

\footnotetext{
${ }^{12}$ Rubin also describes the importance of the invocation of the senses during medieval religious ceremonies: "at the elevation [of the Host] all senses were called into play. Bells pealed, incense was burnt, candles were lit, hands were clasped, supplications were mouthed" (Rubin, 1991). Similarly the first appearance of the Grail in each of the Grail narratives is accompanied by overwhelming sensory sensations for the watching knights. In Chrétien's text the appearance of the Grail is accompanied by a profusion of candles, and is followed by a description of Perceval washing his hands in warm water, and then enjoying a sumptuous meal at the Fisher King's table. In the Queste and the Sankgreal the emphasis on sensory experience in accentuated further. The arrival of the Grail is heralded by a terrifying clap of thunder. A ray of bright light then illuminates the court and all of the watching knights. As the Grail itself appears the palace is filled with a marvellous fragrance, and after it departs the knights are served with the food that they desire.

13 All references to Chrétien's Perceval are taken from Mela (1994). References to translations of Chrétien's Perceval are taken from Kibler (1991) throughout.
} 
[He held back because the gentleman had so gently admonished him not to talk too much, and he kept this warning constantly to heart (p. 421).]

In this section of the text, Chrétien emphasises Perceval's process of deductive reasoning: we not only hear Perceval deciding what course of action to take, but also what the reasons behind his decisions are. Perceval's silence at this moment represents his failure (or inability) to engage in the dialectic questioning that would both have healed the Fisher King and have brought the Grail quest to a successful end. At the same time, the repetition of his reason for remaining silent draws attention to the faulty logic that he deploys to isolate a course of action.

The importance of Chrétien's Grail procession as a visual and demonstrative miracle is clarified in an encounter that Perceval has with his cousin immediately after leaving the Fisher King's castle. When Perceval's cousin establishes that he spent the night at the Fisher King's castle she asks him a series of questions:

Or me dites se vos veïstes

La lance don la pointe saigne,

Et si n'i a ne char ne vaine.

- Se je la vi? Oil, par foi!

- Et demandates vos por coi

Elle saignoit? - N'en parlai onques.

- Si m'aïst Dex, ce saichiez donques

Que molt avez espleitié mal.

Et veïstes vos lo graal? (11. 3486-3494)

["tell me whether you saw the lance with the tip that bleeds, though it has neither blood nor veins"

"Yes, upon my word, I did see it!"

"And did you ask why it bled?"

"I never spoke a word"

"So help me God, let me tell you then that you have done ill. And did you see the Grail?", (p. 424)]

This dialogue specifically connects Perceval's overall failure with his failure to question, and thus to receive the knowledge that would have illuminated his experience. As E. Jane Burns describes, Perceval "is caught in a linguistic trap of questions unasked and answers which remain incomprehensible" (Burns, 1982). It also suggests that a successful interaction with the Grail procession relies upon two moments of spiritual perception and illumination. Witnessing the demonstrative miracle should have inspired Perceval to question what he saw. By questioning, Perceval would have engaged in a further form of spiritual illumination through the receipt of knowledge gained via dialectic reasoning. ${ }^{14}$

14 As Burns explains, the answers to these questions do not immediately provide the illumination for which one might hope. As Burns outlines, when the hermit provides an answer to one of the questions "the curious reply (...) does little to clarify the relationship between the Roi Pescheor, lance and Grail. 
The Didot-Perceval fills in the deductive gaps of Perceval's story with the Christian pre-history provided by the Joseph d'Arimathie that provides a persuasive context for the Grail, and the addition of characters to act as guides. Furthermore, in the Didot-Perceval the arrival of the Grail to Britain, the place where the Grail is kept and the action needed to bring the Grail quest to an end are explained to all of the knights at King Arthur's court by a mysterious voice before the quest begins:

Et quant cil cevaliers sera si essauciés sor tos homes, et ara le pris de le chavelierie del siècle, quant il ara tnt fait si l'asenera Dex le maidon le rice Roi Pescheor, et lors quant il avra demandé que on en fait et cui on en sert de cel Graal, lors quant il ara çou demandé si sera li Roi Peschiere garis, et sera li piere rasoldee del liu de le Table Reonde, et charont li encantement qui hui cest jor son ten le terre de Bretagne (p. 151) ${ }^{15}$

[When such a knight is exalted above all other men and is counted the finest knight in the world, when he has achieved so much, then God will guide him to the house of the rich Fisher King. And then when he has asked what the Grail is for and who is served with it, then, when he has asked that question, the Fisher King will be healed, and the stone will mend beneath the place at the Round Table, and the enchantments which now lie upon the land of Britain will be cast out (p. 120).]

The inclusion of this information before the commencement of the Grail quest significantly reduces the number of deductive steps that Perceval must make alone. Unlike in Chrétien's text, in the Didot-Perceval Perceval does not need to intuitively perceive how to act when faced with the Grail procession. Rather, he should witness the Grail procession (the demonstrative illustration of divine truth), and then be able to recall the earlier instruction that he was given, and thus perceive how to act. However, the Didot-Perceval explains that when Perceval sees the Grail.

Si le tint a molt grant mervelle et leüst molt volentiers demandé, se il ne cremist son oste anoier. Et molt i pensa toute le nuit, mais il li sovint de se mere qui il dist que il ne fust mie trop parlans ne trop demandans des coses. (p. 208)

[he was filled with wonder and would gladly have asked the question - but he was afraid of upsetting his host. He kept thinking about it all that night, but kept remembering how his mother had told him not to talk too much or to ask too many questions. (p. 141)]

Like Chrétien's text, the Didot-Perceval explains Perceval's thought process. Although the Perceval of the Didot-Perceval shows an ability to connect present events to past advice, his choice to follow familial advice rather than spiritual advice

\footnotetext{
Footnote 14 (continued)

The hermit's reply simply generates sets of narrative pairs in line with the originally doubled question" (Burns, 1982).

15 All references to the Didot-Perceval are from Roach (1941). References to the modern English translation are taken from Bryant (2001).
} 
indicates that Perceval is giving precedence to earthly connections over spiritual understanding.

Although achieving the Grail still centres upon a single experience of seeing, interpreting and responding correctly, the Didot-Perceval also includes several secondary moments of perception (and misperception) that illustrate the logical system of this text. One such example occurs just before Perceval encounters the Fisher King. Perceval spends the day riding "onques aventure ne trova ne ostel u il se peüst herbregier" (p. 202) ["without finding any adventure or house where he could lodge" (p. 139)] when suddenly before him he sees "un des plus biaus arbes que il eüst onques mais veü' (p. 203) [“one of the loveliest trees he ever beheld"] which "estoit sor le forc de quatre voies par dejouste une molt bele crois" (p. 203) ["stood beside a beautiful cross at the meeting of four roads" (p. 139)]. While Perceval gazes at the tree in delight "si vit par desus aler deus enfants de brance en brance tos nus, et estoient bien cascuns, ce li sambla, de l'age de sis ans, et acoloit li uns l'autrebet juoient ensamble" (p. 203) ["he saw two naked children climbing from branch to branch, each, he thought, about six years old, and they were hugging together and playing together" (p. 139)]. When Perceval requests that they speak to him "et les conjura del Pere et del Fil et del saint Esperit" (p. 203) ["in the name of the Father, Son and Holy Spirit" (p. 139)] the children explain their role to Perceval before pointing him towards the direction he needs to take:

Cevaliers qui nous as conjurés, saces que de par Dieu vivons nous. Et saces que de cel paradis terrestre dont Adans fu jetés venimes nos por parler a toi par le congié del saint Esperit. Tu es entrés en la queste del Graal que Bron tes taions a en garde, que on apele en mainte contree le Roi Pescheor; et tu t'en iras ceste voie a destre par devant toi, et saces que ançois que tu en isses verras tel cose par quoi tu afineras ton traval se tu es teus que venir i doies. (DidotPerceval, pp. 203-4)

[Know, enquiring knight, that we are indeed God's creatures; and from the earthly paradise from which Adam was exiled we have been sent by the Holy Spirit to speak to you. You have embarked upon the quest for the Grail, which is in the keeping of your grandfather Bron, known in many lands as the Fisher King. Take the path to your right, and before you leave it, be assured, you will see something that will bring you to the end of your quest - if you are worthy to achieve it]. (Bryant, p. 139)]

In case the vision itself is not enough to inspire Perceval's confidence in the advice he is given, the divine children also provide Perceval with a compelling argument as to why he should follow their advice: they are "God's creatures", sent by the Holy Spirit to direct Perceval towards the Grail. However, Perceval is still unable to perceive how he should act, and stops to consider whether he should follow the advice he has been given or not as "se pensa et douta que ce ne fust fanthosmes" (p. 204) ["he was stricken with fear that they might be phantoms" (p. 140)]. When Perceval pauses, a second explanation as to why he should follow the advice of the children is offered by a voice that issues from a shadow and says: 
Perceval, Merlins dont tu as tant oï partler te fait savoir que tu n'aies mie en despit çou que li doi enfant dont ensagnié, car saces que cil ensagnements vient de par Jhesucrist, nostre Sauveor, et se tu es preudom saces que ançois que tu isses del cemin a destre qui par le volenté nostre Segnor t'est ensagniés, aras tu acomplie la prophesie que nostre Sire commanda a Joseph. (p. 204)

[Perceval! Merlin - of whom you have heard so much - sends you word that you should not reject what the children have told you, for their advice comes from Our Saviour Jesus Christ. If you are worthy, before you leave the righthand path to which you have been directed by Our Lord's will, you will fulfil the prophecy that Our Lord made to Joseph. (p. 140)]

This second explanation draws upon the authority not just of God (as the advice offered by the divine children does), but also of Joseph of Arimathea and Merlin, and thus the earlier two parts of the Trilogy. It appears to be this, and not the reference to God alone, that persuades Perceval to follow the advice he has been given. Through using the earlier parts of the text in this way, the Didot-Perceval draws upon an intra-textual system of authority and justification that provides some of the dialectic explanation of why Perceval should complete a certain action.

In the Queste, the interaction between the knight's experience of a demonstrative miracle, and the dialectic reasoning and explanation is amplified further and structures the episodic sequence of the narrative. Rather than revolving around a single moment of perception and comprehension, the knights are given frequent opportunities to "learn" how to read the logic of the text. The quest for the Grail is also transformed from an individual quest that only the rightful knight partakes in, into a community undertaking in which each Grail miracle provides an opportunity for the knights to improve their spiritual understanding by a reiterative pattern of experience. Explanations of each aventure are provided to the knights (and thus also the reader), by a profusion of hermits, priests and other religious figures who inhabit the Grail forest, and these explanations mark the end of a particular narrative sequence.

One of the clearest examples of this narrative structure can be seen in the Queste's description of Bohort's individual adventures. ${ }^{16}$ At the beginning of this episode Bohort has two visions. In the first,

a senestre partie loign de lui un fust porri et vermeneus, si foible que a poines se pooit sostenir en estant; et a destre avoit deus flors de lys. L'une des flors se traoit pres de l'autre et li voloit sa blanchor tolir. (p. 171) ${ }^{17}$

\footnotetext{
16 Although the Queste gives us an insight into each of the knights' thought processes, of the three most successful Grail knights the Queste devotes the most description to Bohort's ability to reason. Galahad is depicted as being able to follow the right course of action unfailingly and instinctively and the text tells us very little about his internal thoughts. Although Perceval is shown to make mistakes, the text also gives little description to his thought processes. On the two occasions when Perceval makes the wrong choice, and allows himself to be tricked by the enemy, he saves his soul by making the sign of the cross. Perceval performs this physical devotion in response to feeling fear, rather than because he reasons that it is the correct action to take.

17 References to the Queste del Saint Graal are taken from Pauphilet (1984). All references to the modern English translation of the Queste are to Burns (2010).
} 
[to his left, some distance away, there was a rotten, worm-eaten tree trunk, so weak that it could hardly stand. To the right there were two lilies of the valley. One of the flowers bent toward the other and tried to deprive the second of its whiteness. (p. 106)]

The lilies are separated by a man who is seated on a throne, and who tells Bohort that he should "Or te garde donc [...] que se tu voiz tele aventure avenir, que tu ne lesses pas ces flors perir por le fust porri secorre" (p. 171) ["take care that if such an adventure should occur, you do not allow the flowers to perish for the sake of the rotten tree" (p. 106)]. The vision that Bohort encounters in his dream acts as a demonstrative argument: the divine truth that this lesson is supposed to teach Bohort is instantaneously visible to him in this vision, but only if he is able to perceive it. Two days later Bohort meets with "une aventure merveilleuse" (p. 175) at a crossroads and is forced to choose between saving his brother Lionel, who is being beaten and led away by two knights, and saving a young girl who has been abducted by a knight. At this point the Queste begins to blur "the distinction between romance adventure and dream", and the truth exemplified by the dream becomes a physical aventure that Bohort must overcome (Burns, 1982). Although Bohort chooses to act correctly and to save the young girl, the text makes no overt suggestion that Bohort himself connects the vision he has witnessed to the reality of the events that he encounters.

The importance of interpretation and understanding are further highlighted by Bohort's interaction with a false priest. When Bohort meets the priest and asks him to interpret the dreams that he has had (further indicating that he is not able to follow the deductive process independently) the false priest draws upon Bors' understanding of priorities in the secular chivalric world, and invokes the relationships that mean the most to Bohort within this context. Through threatening the deaths of Lionel and Lancelot should Bohort fail to respond correctly, the priest draws upon the precedence that homosocial bonds between the Knights of the Round Table take in the secular Arthurian world and earlier parts of the Morte Darthur. ${ }^{18}$ This emphasis on the value of secular chivalry is further accentuated by the priest as he interprets Bohort's former actions:

Et por ce porra len bien dire que tu es homicides de l'une et de l'autre, ausi com tu as esté de ton frere, qui le poïsses avoir resques aiseement se tu vouisisses [...] Or resgarde ou il a greignor domage, ou en ce que ele fust despucelee, ou en ce que tes freres, qui est un des bons chevaliers dou monde. (p. 179)

[we will be able to say that you have murdered them both, as you have killed your own brother. Yet you could have saved Lionel easily, if you had wanted

\footnotetext{
18 In this case the bonds are doubly important, as Bohort has a biological connection to both Lionel and Lancelot. Lionel is not only Bohort's biological brother, he is an Knight of the Round Table, and thus his sworn brother in arms. Lancelot has a similar familial tie to Bohort as his cousin-german, but also holds a further significance in his pre-Grail quest position of the best of all earthly knights.
} 
to [...] Consider where the most damage was done: in the rape of the maiden or the death of your brother, one of the world's finest knights (p. 111)]

This moment represents a direct challenge to Bohort's interpretative faculties. Both Bohort and the reader are expected to be able to perceive the flaws in this explanation through their understanding of Christian doctrine, and recognition of the fact that any logical process which is based on the precedence of the secular Arthurian world will not work in the Grail quest.

Although Bohort is unable to overtly recognise that the interpretation of his past actions is false, the compelling interpretation of events to come, threatening the death of Lancelot, does not inform his subsequent decision about how to act. When faced with a beautiful woman who threatens to kill herself along with twelve maidens if he does not agree to be her lover Bohort ignores the warning of the false priest and chooses to take the correct course of action:

Et il les esgarde et cuide veraiement que ce soient gentilx fames et hautes dames; si l'em prent grant pitié. Et neporquant il n'est pas conseilliez qu'il ne vueille mielz qu'eles toutes perdent lor ames que il seuls perdist la soe: si lord it qu'il n'en fera riens, ne por lor mort ne por lor vie. (pp. 181-182) [Bors looked at them, thinking what noble women and highborn ladies they were, and he felt pity for them. Yet he was not of a mind to lose his soul in order to save theirs. So he told them he would do nothing, regardless of whether they lived or died. (p. 113)]

Bohort is shown to be able to apply his own understanding of Christian doctrine to the physical aventures of the Grail quest, and therefore succeeds. The false priest's invocation of more secular chivalric values, relationships and priorities further highlights the gulf between former chivalric behaviour and expectations and those required for success in the Grail quest.

When Bohort finally finds a true abbot to interpret his experiences, the abbot provides an exegetical explanation of all the events that Bohort has encountered since meeting the first priest, relating Bohort's choice at the crossroads to his earlier vision of the lilies:

Li fuz sanz force et sanz vertu senefie Lyoniax, tes freres, qui n'a en soi nule vertu de Nostre Seignor qui en estant le tiegne. La porreture senefie la grant plenté de pechiez mortiex qu'il a en soi amoncelez et acreuz de jor en jor [...] Par les deus flors qui estoient a destre sont senefiédui vierge; si en est li uns li chevaliers que vos navrastes ier, et l'autre la pucele que vos resqueusistes. (p. 186)

[The tree without sap or strength represents your brother Lionel, who has none of the virtues of Our Lord that you possess. The rotten wood represents the abundance of mortal sins that he has accumulated from day to day within himself [...] The two flowers to your right represent virgins. One is the knight whom you wounded yesterday, and the other the maiden that you rescued. (pp. 115-116) 
In choosing to rescue the maiden, the abbot explains that Bohort has acted in accordance with the warning of the vision. The abbot's explanation subsequently fills in any dialectic gap in Bohort's understanding, and clarifies both the events of the narrative and the Christian reasoning behind the choice that Bohort faced. Bohort's experience illustrates a progression from the vision in the dream (the initial demonstrative argument), to diegetic events (the physical aventure that is designed to test Bohort's ability to reason), and finally to the explanation of the same events through Christian theology, as "the reader is made to come full circle in a loop" (Burns, 1982). Once Bohort fully perceives the meaning and significance of the narrative he is able to make a physical move onto another aventure, which marks the close of this episode within the narrative. This structure of demonstrative miracle, diegetic adventure, and dialectic interpretation, is repeated throughout the Queste to describe the experiences of all of the knights, and is replicated by Malory in the Sankgreal.

Critics have frequently noted that Malory greatly redacts the religious interpretations of the Grail miracles offered by his principal source. Traditionally, this redaction has been used to suggest that Malory misunderstands, misperceives or simply has no interest in the religious significance of his source. As has been widely cited, C. S. Lewis suggested that "a case can be made out for the view that Malory evaded the religious significance" of the Queste through the omission of many of the longer religious explanations of the Grail miracles (Lewis, 1963). Similarly, in his early scholarship, Eugène Vinaver described the Sankgreal as "a confused and almost pointless story, a beautiful parade of symbols and bright visions" (Vinaver, 1929). In the 1980 s, however, scholarship started to attribute more significance to the way in which Malory adapted his sources. Sandra Ness Ihle's Malory's Grail Quest: Invention and Adaptation in Medieval Prose Romance (1983), for example, discusses the various ways in which Malory adapted the Queste to build his own version of the Grail story. This focus has been retained in more modern scholarship. Dhira B. Mahoney suggests that in the Sankgreal Malory expresses "the thirteenth-century spiritual message in language and thought that is characteristic of the religious temper of fifteenth century England" (Mahoney, 2000). Most recently, Sarah B. Rude argues that although "certainly Malory was not a university-educated theologian, and we, as readers, cannot expect him to provide an "abstract, analytic" explanation of the metaphysical effects associated with the Eucharist", he appreciates and discusses the religious significance of the Grail from the viewpoint of a fifteenth-century Christian gentleman (Rude, 2018). I build upon this later scholarship to suggest not only that Malory retains the religious significance of his source, but that the way in which he chooses to redact the French Grail quest indicates a deliberate interaction with the processes of logic described in each of the earlier Old French Grail narratives. Although Malory may greatly redact his source material, these redactions do not disrupt the sequencing pattern illustrated by the Vulgate Cycle Queste; the order and structure created from the processes of learning and interpretation remains the same. I would also suggest that in many cases although Malory shortens the length of the dialectic explanation offered, he "always preserves the core of the French book's doctrinal statements” (Moorman, 1956). 
When it comes to describing Bors' individual aventures Malory follows the narrative of his source closely, ensuring that the relationship between demonstrative miracles and dialectic explanation remain the same as in the Queste. The only change that Malory makes to the order of the Queste's narrative is to move Bors' confession at the opening of the narrative sequence to the first night that he stays in the hermitage. Malory's treatment of the opening of this sequence, where Bohort meets a "good man" (p. 731) and is "clene confessed" (p. 731), represents one of his most significant redactions to this episode. In the Queste the interaction between Bohort and the good man centres on a lengthy explanation of the significance of confession. ${ }^{19}$ Malory substitutes the entire explanation of confession for an actual confession scene, writing "And so [Bors] alyghte and put of hys armoure and prayde hym that he myght be confessed, and so they wente into the chapell and there he was clene confessed" (p. 731). In moving Bors' confession scene to the first evening he stays at the hermitage (rather than it taking place the following morning, as in the Queste) Malory replaces explanation with action. Felicity Riddy suggests that in the Sankgreal Malory "has assimilated the monastic values of the Queste into the introspective and interior religion of the fifteenth-century gentry" (Riddy, 1987). In turning the explanation of confession into an act of confession Malory simultaneously reminds the reader about the importance and meaning of confession, while highlighting the private nature of this communication with God.

The description of Bors' aventures in the Sankgreal also highlights the way in which Malory redacts his source material without removing or lessening the dialectic significance of the miracles themselves. In the Queste, the abbot's explanation of the pelican who kills itself to revive its young, for example, goes through the specific significance of the bird, the young birds and the tree, relating each one to a piece of biblical history and then providing a lengthy explanation of it. Malory redacts this by approximately two thirds, writing.

Oure Lord shewed Hym unto you in the lyknesse of a fowle, that suffirde grete anguysshe for us whan He was putte uppon the Crosse, and bledde hys herte blood for mankynde; there was the tokyn and the lyknesse of the Sankgreall that appered afore you, for the blood that the grete flowle bledde reysyd the chykyns frome dethe to lyff. And by the bare tre is betokened the worlde, whych ys naked and nedy, withoute fruyte but if hit com of Oure Lorde (p. 741).

This explanation is not a direct translation of the Queste but, although significantly shorter, it also retains all of the important significances described in the French text. Malory's explanation of the miracle clarifies the miracle's significance, without providing the level of detailed exegesis given by his source. Rather, some of these connections are left for Bors and the reader to make independently. Through

\footnotetext{
19 In the Queste this explanation is approximately 550 words in length. The space occupied by this explanation of confession is taken from an edition of New Haven, Yale, MS Yale 229, in which manuscript it occupies 238v a (line 7) to $239 \mathrm{r}$ a (line 4).
} 
placing the Grail between Christ's sacrifice for mankind and the pelican's sacrifice for its young, Malory draws together Salvation history, the literary Arthurian past, and the Christian present of medieval England.

P. J. C. Field notes that throughout the Morte Darthur as a whole Malory creates "a vivid factual-seeming narrative, but one that tends to leave causes and relationships obscure" (Field, 2008). In some ways Malory's text represents a return to the patterns followed by some of the earlier narratives, where the knights (and readers) are left to make some of the deductive steps intuitively. As a medieval audience watches Bors go to confession, they are reminded about the important part that confession should play in their own lives; as they hear the abbot's explanation of what each element of Bors' vision of the pelican stands for, their own Christian understanding fills in the connection between each element, enabling them to interpret the miracle for ourselves. In this way, the Sankgreal transforms the knights into readers, and readers into questing knights. Wade suggests that.

when readers construct fictional worlds they fill in the gaps in the text by assuming a familiarity with their own experience, other narratives participating in an audience's imaginative network will always shade the reception of any given text (Wade, 2011).

In the Sankgreal, the knights' understanding of former secular adventures has a significant impact on their ability to read the logic of the Grail quest. Gawain, for example, who refuses to confess or do penance as "we knyghtes adventures many tymes suffir grete woo and payne" (p. 691) is unable to find any aventures at all, whereas Bohort, who engages, reasons, and relates his decisions to the state of his soul progresses rapidly. ${ }^{20}$ As readers we are also encouraged to compare the values and priorities of the Grail quest world with those set by earlier parts of the Arthurian cycle. We are asked to apply our own sense of reasoning, logic and understanding to the decisions made by the knights, and then to work outwards, to consider what these lessons may tell us about our own experience of life.

Malory's redactions suggest not just a process of adaptation, but the creation of an intertextual dialogue, where the answers and interpretations of miracles not fully cited in the Sankgreal can be found in his primary source. It is notable that even though Malory redacts many of the dialectic explanations provided for the Grail miracles he keeps the narrative sequence of events that is a product of the use of the interaction between the hermits and the knights; those who "do" and those who "know". Although I have only discussed one example, this pattern is repeated throughout the narrative of the Sankgreal. Additionally, in places where we see Malory changing or redacting his source, he preserves the narrative pattern found in the earlier Old French Grail narratives in a way that suggests a clear interaction with

\footnotetext{
${ }^{20}$ It is important to note that Bors does not begin the Grail quest with the level of perfection of Perceval and Galahad, who are both virgins. In this way, Bors' story in both the Queste and the Sankgreal becomes a narrative of redemption, not dissimilar in nature from Lancelot's Grail narrative, but with the fundamental difference related to Bors' ability to reason and Christian stability. Bors is able to look at the world around him and perceive the correct course of action. He is also able to listen to the advice of the various religious figures that he meets, and follow it successfully.
} 
the earlier ideas. ${ }^{21}$ This indicates that even though he was writing over two hundred years after his latest source Malory chooses to draw back to this earlier mode of logical representation to illustrate the miracles of the Grail.

\section{Conclusion}

To fully explore the logical systems at work in the Old French and Middle English Grail narratives an extended study would be required. Through taking a single example from each text, I hope to have shown the way in which the relationship between miracle and explanation, the knight's actions and the hermits' speeches, can be more fully comprehended though a comparison with dialectic and demonstrative models of argumentation. It is the interaction with both demonstrative miracle and dialectic reasoning that brings an aventure to a successful close. At the same time, the similarities in the conceptualisation of logic deployed by each text further highlight the genetic relationship between Grail quest narratives suggested by Tether. In turn, appreciating the way in which Malory redacts his primary source, reducing the length of exegetic explanations without changing the meaning of the aventures, indicates that rather than attempting to reduce the religious significance of his Grail quest, Malory is responding to a model of illumination and understanding that is prevalent in the earlier Old French Grail narratives. Appreciating this model of analysis also helps to clarify the significance and purpose of some of the changes that Malory makes to his source. Malory's redactions highlight an interaction with the logical theories prevalent in his Old French sources (as can be seen in the distinctive narrative pattern of the Sankgreal, which follows that of the Queste) but that reflects the character of fifteenth-century English religious thought and feeling. Questions surrounding the logic employed by Malory feed into scholarly debates surrounding Malory's treatment of the Grail material. If we view Malory as not just replicating, but actively responding to the narrative and structuring patterns, and thus systems of logic, present in his Old French source material, we can view Malory as being an active participant in the transmission and preservation of the spiritual elements of the Grail quest.

Funding Open Access funding enabled and organized by Projekt DEAL.

Open Access This article is licensed under a Creative Commons Attribution 4.0 International License, which permits use, sharing, adaptation, distribution and reproduction in any medium or format, as long as you give appropriate credit to the original author(s) and the source, provide a link to the Creative Commons licence, and indicate if changes were made. The images or other third party material in this article are included in the article's Creative Commons licence, unless indicated otherwise in a credit line to the material. If material is not included in the article's Creative Commons licence and your intended use is not permitted by statutory regulation or exceeds the permitted use, you will need to obtain permission

\footnotetext{
${ }^{21}$ I am not suggesting that Malory was consciously responding to ideas of logic contained within Chrétien's Perceval or the Didot-Perceval, but rather than the principles that structure Malory's later narrative are inherently connected to the conceptualizations of logic that can be seen in various forms in each of the Old French Grail narratives.
} 
directly from the copyright holder. To view a copy of this licence, visit http://creativecommons.org/licen ses/by/4.0/.

\section{References}

Archibald. E. (2018). Malory and the post-Vulgate cycle. In E. Archibald, M. Leitch, and C. Saunders (Eds.), Romance rewritten: A tribute to Helen Cooper (pp. 115-132). Boydell and Brewer.

Archibald, E. (August 1992). Malory's ideal of fellowship. The Review of English Studies, 43(171), 311-328.

Bouchier, E. S. (1901). Aristotle's posterior analytics. Clarendon.

Bryant, N., trans. (2001). Merlin and the grail: The trilogy of Arthurian romances attributed to Robert de Boron. Woodbridge.

Burns, E. J., trans (2010). The quest for the Holy Grail. D. S. Brewer.

Burns, E. J. (1982). The doubled-question test: Mystic discourse in Chrétien's Perceval. Romance Notes, 23(1), 57-64.

Chaucer, G. (2008). The Wife of Bath's Prologue. In L. D. Benson (Ed.), The Riverside Chaucer (pp. 105-121). Oxford University Press.

Crofts, T. (2006). Malory's contemporary audience: The social reading of romance in late medieval England. Boydell and Brewer.

Evans, J. D. G. (1977). Aristotle's concept of dialectic. Cambridge University Press.

Field, P. J. C. (2008). Malory and the grail: The importance of detail. In N. J. Lacy (Ed.), The grail, the quest, and the world of Arthur. D. S. Brewer.

Field, P. J. C. (Ed.) (2017). Le Morte Darthur. D. S. Brewer.

Gilson, É. (1925). La mystique de la grâce dans la Queste del saint Graal. Romania, 203, 321-347.

Greene, V. (2014). Logical fictions in medieval literature and philosophy. Cambridge University Press.

Hunt, T. (1977). The dialectic of Yvain. Modern Language Review, 72(2), 285-299.

Kavanagh, C. (2003). Eriugenian developments of Ciceronian topical theory. In Stephen Gersh and Bert Roest (Eds.), Medieval and renaissance humanism: Rhetoric, representation and reform (pp.1-30). Brill.

Kelly, D. (1992). The art of medieval French romance. University of Wisconsin Press.

Kibler, W., \& trans. (1991). Chrétien de troyes: Arthurian romances. Penguin.

Lewis, C. S., (1963). The English prose Morte. In J. A. W. Bennett (Ed.), Essays on Malory (pp. 7-28). Clarendon.

Mahoney, D. B. (2000). The truest and holiest tale: Malory's transformation of La Queste del Saint Graal. In D. B. Mahoney (Ed.), The grail: A casebook (pp. 379-396). Garland.

Marenbon, J. (1987). Later medieval philosophy. Routledge \& Kegan Paul.

Matarasso, P. (1979). The redemption of chivalry. Librairie Droz.

Matarasso, P. (1969). The quest of the Holy Grail. Penguin.

Matarasso, P., trans. (1969). The quest of the Holy Grail. Penguin.

Mela, C., ed. and trans. (1994). Chrétien de Troyes: Romans. Paris, FR.: Librairie Générale Française.

Moorman, C. (1956). Malory's treatment of the Sankgreal. PMLA, 71, 496-509.

Olsen, C. (2007). Patient Lancelot and impatient Gawain in the Queste del Saint Graal. Arthuriana, $17(4), 3-28$.

Pauphilet, A. (1921). Etudes sur la queste del Saint Graal, attribuée à Gautier Map. Protat Frères.

Riddy, F. (1987). Sir Thomas Malory. Brill.

Roach, W. (Ed.). (1941). The Didot-Perceval. University of Pennsylvania Press.

Rubin, M. (1991). Corpus Christi. Cambridge University Press.

Rude, S. B. (2018). Seeing is believing and achieving: Viewing the Eucharist in Malory's 'Sankgreal.' Arthuriana, 28(2), 3-27.

Stump, E. (1986). Dialectic. In D. L. Wagner (Ed.), The seven liberal arts in the Middle Ages (pp. 125146). Indiana University Press.

Tether, L. (2017). Publishing the Grail in medieval and renaissance France. D. S. Brewer.

Vinaver, E. (1929). Malory. Clarendon.

Wade, J. (2011). Fairies in medieval romance. Palgrave Macmillan. 
Wade, J. (2013). Arbitrariness and knowing in Malory's Morte Darthur, Book 4.18-21. Studies in Philology, 110, 18-42.

Whetter, K. S. (2005). On misunderstanding Malory's Balyn. In K. S. Whetter and Raluca L. Radulescu (Eds.) Re-viewing Le Morte Darthur (pp. 149-62). D. S. Brewer.

Publisher's Note Springer Nature remains neutral with regard to jurisdictional claims in published maps and institutional affiliations. 